\title{
The Policies of Seismic Risk Management: Case of the Protected Areas of Dellys and Tenes Cities, Algeria
}

\author{
Farida Sehili and Said Madani \\ Laboratory PUViT, University of Ferhat Abbas, El Bez 19000, Sétif Algeria
}

\begin{abstract}
The greater part of urban heritage, especially of the medium and small Algerian cities, is subject to a major seismic risk. The probability of a happening earthquake is strong, and the territories vulnerability is great. Legislative procedures are implemented to support urban heritage and managing natural disasters. In fact, the PPSMVSS (permanent plan of safeguard and enhancement of saved sectors) as an instrument of protection, preservation and enhancement of this heritage, in its content, does not guide decision makers on how to manage the vulnerability of preserved areas from the earthquake. After the disaster of the earthquake that hit the Algerian Centre (wilaya of Boumerdes) in 2003. A legislative framework was created while other texts have been adapted. Emergency measures operations are launched to preserve the under threat monuments and protected areas. Saved sectors of Dellys, in the wilaya of Boumerdes and Ténès in the wilaya of Chlef, are all the time subjected to seismic risk. This article presents a comparative study of two PPSMVSS, Dellys and Ténès, and the management of the vulnerability of their two safeguarded areas. As a result of this study, some indicators were identified to allow the development of plans for the protection and management natural risks of these protected areas.
\end{abstract}

Key words: Safeguarded sector PPSMVSS, catastrophe, seismic risk, management.

\section{Introduction}

Algeria has a rich cultural and natural heritage stunning by its historical and symbolic significance, witnessed the passage of many civilizations. This is an invaluable archaeological, architectural and urbanistic variety.

Conservation and enhancement of this heritage were needed for Algerians particularly makers, for real cultural property. The strategy put in place to preserve the heritage has been since independence, in the identification and protection by filing or registration on an additional inventory, the various historic monuments and sites.

\section{Tools to Protect Safeguarded Areas}

After the promulgation of the law 98-04 of June 15, 1998 on the protection of cultural heritage, protective, safeguard and enhancement measures are implemented for each type of immovable cultural property. Urban

Corresponding author: Farida Sehili, Ph.D. architecture student, research field: urban risk management. E-mail: sehilifarida@gmail.com. and rural groups are protected by creating conservation areas.

Articles 17 and 41 of the above mentioned law establish the criteria for historic monuments, safeguarded sector, urban and rural housing developments, such as Kasbahs, Medinas, Ksour, villages and traditional towns. The first is defined as any isolated or grouped architectural design that reflects a particular civilization in a significant development and a historic event [1].

Concerning urban and rural real estate, they must meet the following criteria: homogeneity, architectural unity, aesthetic unity, historical interest, architectural interest, artistic or traditional interest to justify the protection, restoration, rehabilitation and enhancement.

The folder concerning the creation and delimitation of saved sectors is published by decree. These areas feature a PPSMVSS (permanent safeguard and enhancement plan). It takes place in a POS (land use plan).

Since the promulgation of the law on the protection of heritage, seventeen conservation areas are created 
Table 1 Status of saved sectors in Algeria.

\begin{tabular}{|c|c|c|c|c|}
\hline Wilayas & Saved sectors & Number of pop. & Number of built & Establishing decree of the saved sectors \\
\hline Algiers & Casbah of Algiers & 55,000 & 2,200 & No. $05-173$ in May 9, 2005 \\
\hline Constantine & Old town of Constantine & 35,000 & 1,164 & No. 05-208 in June 4, 2005 \\
\hline Chlef & Old town of Ténès & 1,360 & 300 & No. 07-277 in Sep. 18, 2007 \\
\hline Laghouat & Old kzar of Laghouat & 1,500 & 622 & No. 11-141 in March 28, 2011 \\
\hline Bejaïa & Old town of Bejaïa & 13,500 & 3,118 & No. 13-187 in May 6, 2013 \\
\hline Biskra & Dachra El-Hamra & 4,200 & 700 & No. 13-185 in May 6, 2011 \\
\hline Tlemcen & Old town of Tlemcen & - & - & No. $09-403$ in Nov. 29, 2009 \\
\hline Tlemcen & Old town of Nedroma & - & - & No. $09-402$ in Nov. 29, 2009 \\
\hline Tizi-Ouzou & village Ait El Kaid & - & - & No. $09-405$ in Nov. 29, 2009 \\
\hline Annaba & Old town of Annaba & 600,000 & - & No. 13-186 in May 6, 2013 \\
\hline Ouargla & Old ksar of Ouargla & 8,000 & 2,300 & No. 11-142 in March 28, 2011 \\
\hline Ouargla & Ksar of Témacine & - & - & No. 13-184 in May 6, 2013 \\
\hline Boumerdes & Old town of Dellys & 2,867 & 633 & No. 07-276 in Sep. 18, 2007 \\
\hline Ouargla & Ksar of Témacine & - & - & No. 13-184 in May 6, 2013 \\
\hline El Oued & $\begin{array}{l}\text { Neighboured of Echeche } \\
\text { and Messaaba }\end{array}$ & - & - & No. 11-140 in March 28, 2011 \\
\hline Mila & Old town of Mila & - & - & No. $09-404$ in Nov. 29, 2009 \\
\hline Ghardaïa & Valley of M'Zab & 181,263 & 39,916 & No. 05-209 in June 4, 2005 \\
\hline
\end{tabular}

Source: national agency of the saved sectors 2014.

and defined (Table 1).

\subsection{The Contents of the Permanent Safeguard and} Enhancement Plan of Conservation areas (PPSMVSS)

The classified or inventoried sectors are protected by creation and delimitation. Once declared, they are covered by a PPSMVSS (permanent safeguard and enhancement plan of conservation areas). ${ }^{1}$

The content and the various stages of the plan are divided into three phases defined as follows:

- Phase 1: diagnosis and if necessary emergency measures project;

- Phase 2: historical and hippological analysis and draft of PPSMVSS;

- Phase 3: final drafting of permanent safeguard and enhancement plan of conservation areas.

The plan consists of a presentation report that highlights the current state of the conservation area and outlines emergency measures taken for its conservation and enhancement. The PPSMVSS is referring to the PDAU (director plan of management and urbanism),

${ }^{1}$ Executive Decree No.03-324 on October 5, 2003 laying down detailed rules of establishment PPSMVSS. and shows the following synthesized aspects: the frame of the conservation status, condition and layout of road networks, water supply and irrigation of disposal of rainwater and waste water; the removal and disposal of solid waste; the demographic and socio-economic aspect; economic activities and equipment; the legal nature of real estate and demographic and socio-economic perspectives and the proposed programs of public facilities.

The procedure fixes the general rules of land use and the constraints, as well as the operations under consideration within the framework of the development. The regulation should also include, as applicable, the content of Article 18 of Executive Decree No. $91-178$ of May 28, $1991 .^{2}$ A plan for geotechnical constraints, a plan of servitudes and a plan on the conservation status specifying the degree, nature and the cause of buildings deterioration and undeveloped areas and other typological plans [2,3].

It is particularly striking to note the general state of

\footnotetext{
${ }^{2}$ Executive Decree No. 91-178 on May 28, 1991, amended and supplemented, laying down the procedures for the preparation and approval of land use plans as well as the content of documents relating thereto.
} 
degradation of this heritage. Consolidation works, with their rows of scaffolding and shoring, are ubiquitous in urban landscapes.

While historic buildings are closed to the public for security reasons. This is the case of several monuments (Katchaoua mosque and the palace of the Dey) in the city alone Algiers (Fig. 1).

At this stage, the PPSMVSS do not point in its content, decision makers on how to manage the vulnerability of protected sectors from the earthquake.

\section{The Seismic Risk Management Policies of Safeguarded Areas of Dellys and Ténès}

Progressive loss of heritage assets, following natural hazards, alerted UNESCO (United Nations Educational, Scientific, and Cultural Organization) for the establishment of a manual to manage disaster risks for world heritage. Earthquakes cause huge losses to the heritage which plays important role in social cohesion and sustainable development [4, 5]. Faced with this situation, UNESCO set up a risk reduction plan related to natural disasters. Managers and heritage decision makers do not see the vulnerability of heritage as a priority until the advent of the disaster $[6,7]$.

After the disaster of the earthquake in Algeria in 2003, a legislative framework was established while other texts have been adapted to support this natural phenomenon.

There are several provisions on the prevention of major risks at different territorial and urban scales.
Table 2 highlights the gap between the measures to protect the cultural heritage property and the prevention of major risks.

The law No. 05-04 relating to the planning and urban planning with its executive orders, demands, in the development of instruments, to identify and classify seismic zones according to their degree of vulnerability and establish a map defining "areas exposed to natural and technological hazards, along with technical reports, as well as the major risks arising from general prevention plan".

The delimitation of areas and exposed land to natural hazards is carried out according to the means of geotechnical and seismic micro-zoning, at the scale of the land use plan.

The areas and land exposed to natural hazards and/or technological, classified according to their degree of vulnerability, are transcribed on the land use plan as proposed by the services responsible for urban planning, territorial jurisdiction, in the same way that prevailed approval of the plan.

Following the amendment of the articles concerning the land use plan that came after the 2003 earthquake, the delimitation map of the areas exposed to natural hazards is required for the land use plan. And as PPSMVSS refers in its content to the land use plan and the plan of development and urban planning [8, 9]. What about the PPSMVSS of the two cities, Dellys and Tenes?

The two old towns of Dellys and Ténès were created

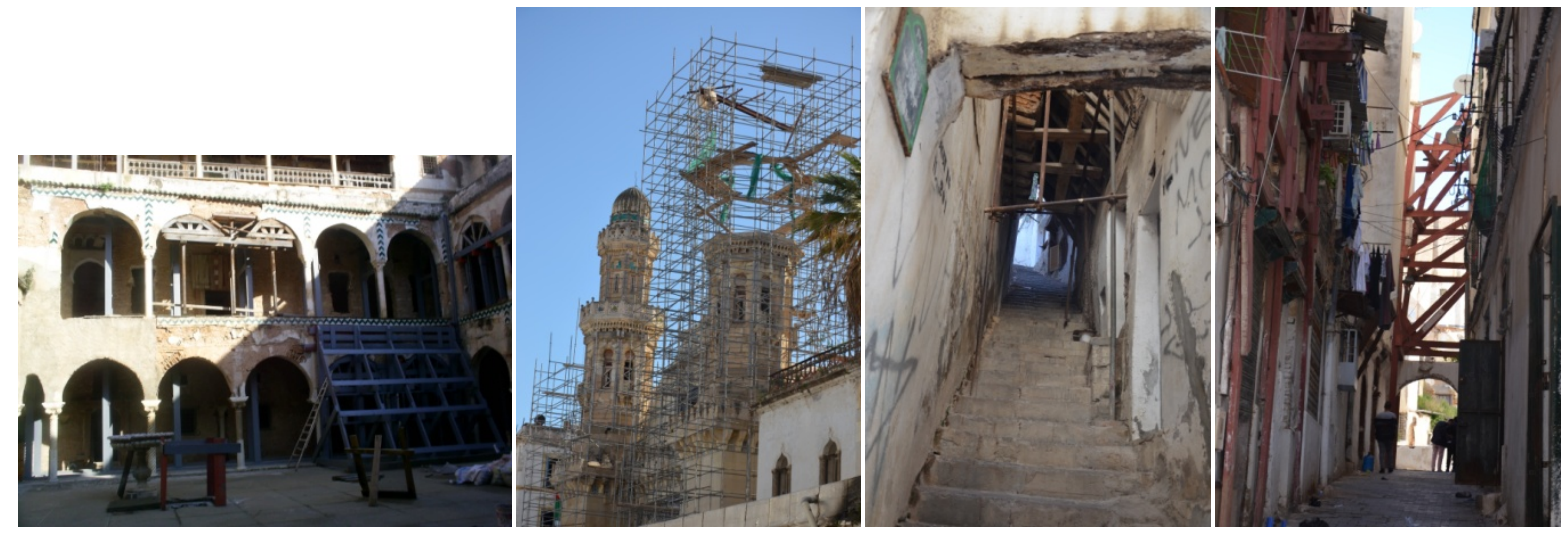

Fig. 1 From left to the right: the palace of the dey, mosque Katchaoua, Kasbah of Algiers.

Source: the authors. 
Table 2 Gap between heritage protection and prevention of major risks.

\begin{tabular}{|c|c|c|c|c|}
\hline \multirow{2}{*}{ Issues } & \multicolumn{4}{|l|}{ Domains } \\
\hline & Key date & Conservation of cultural heritage & Key date & The prevention of major hazards \\
\hline \multirow{3}{*}{$\begin{array}{l}\text { Root } \\
\text { concept } \\
\text { approach } \\
\text { tools }\end{array}$} & 1962 & $\begin{array}{l}\text { Law No. } 62-157 \text { relative to the protection of } \\
\text { historic sites and monuments and natural. } \\
\text { The Ordinance No. } 281 \text { on Dec. } 20,1967 \\
\text { relating to the archaeological excavations } \\
\text { and to the protection of historic sites and } \\
\text { monuments and natural. }\end{array}$ & $\begin{array}{l}1989 \\
2001\end{array}$ & $\begin{array}{l}\text { The Act No. 01-20 on December 12, } 2001 \text { relating to the } \\
\text { planning and the sustainable development of the } \\
\text { territory. } \\
\text { The Act No. } 03-10 \text { on July 13, } 2003 \text { relative to the } \\
\text { protection of the environment in the framework of } \\
\text { sustainable development. }\end{array}$ \\
\hline & 1998 & $\begin{array}{l}\text { Law No. } 98-04 \text { on June } 15,1998 \text { relative to } \\
\text { the protection of the cultural heritage. }\end{array}$ & 2004 & $\begin{array}{l}\text { Law No. } 05-04 \text { on August } 08,2004 \text { relating to land use } \\
\text { planning and development. } \\
\text { Law No. } 04-20 \text { on December } 25,2004 \text { relative to the } \\
\text { prevention of major hazards and disaster management } \\
\text { within the framework of sustainable development. }\end{array}$ \\
\hline & 2003 & $\begin{array}{l}\text { The Decree No. } 03-324 \text { on October } 5,2003 \\
\text { laying down detailed rules for the } \\
\text { establishment of the PPSMVSS. }\end{array}$ & 2005 & $\begin{array}{l}\text { Law No. } 89-26 \text { on December } 31,1990 \text {, bringing finance } \\
\text { act for } 1990 \text { to put in place the funds of natural disasters } \\
\text { and major technological risks. } \\
\text { The regulation Algerian earthquake } 99 \text { revised in } 2003 \text {; } \\
\text { Executive Decree No. } 05-317 \text { on September } 10,2005 \text {, } \\
\text { laying down the procedures for the preparation and } \\
\text { approval of the master plan for management and urban } \\
\text { planning; } \\
\text { Executive Decree No. } 05-318 \text { on September } 10,2005 \text {, } \\
\text { laying down the procedures for the preparation and } \\
\text { approval of the land use plan as well as the content of } \\
\text { documents relating thereto. }\end{array}$ \\
\hline
\end{tabular}

Source: the authors
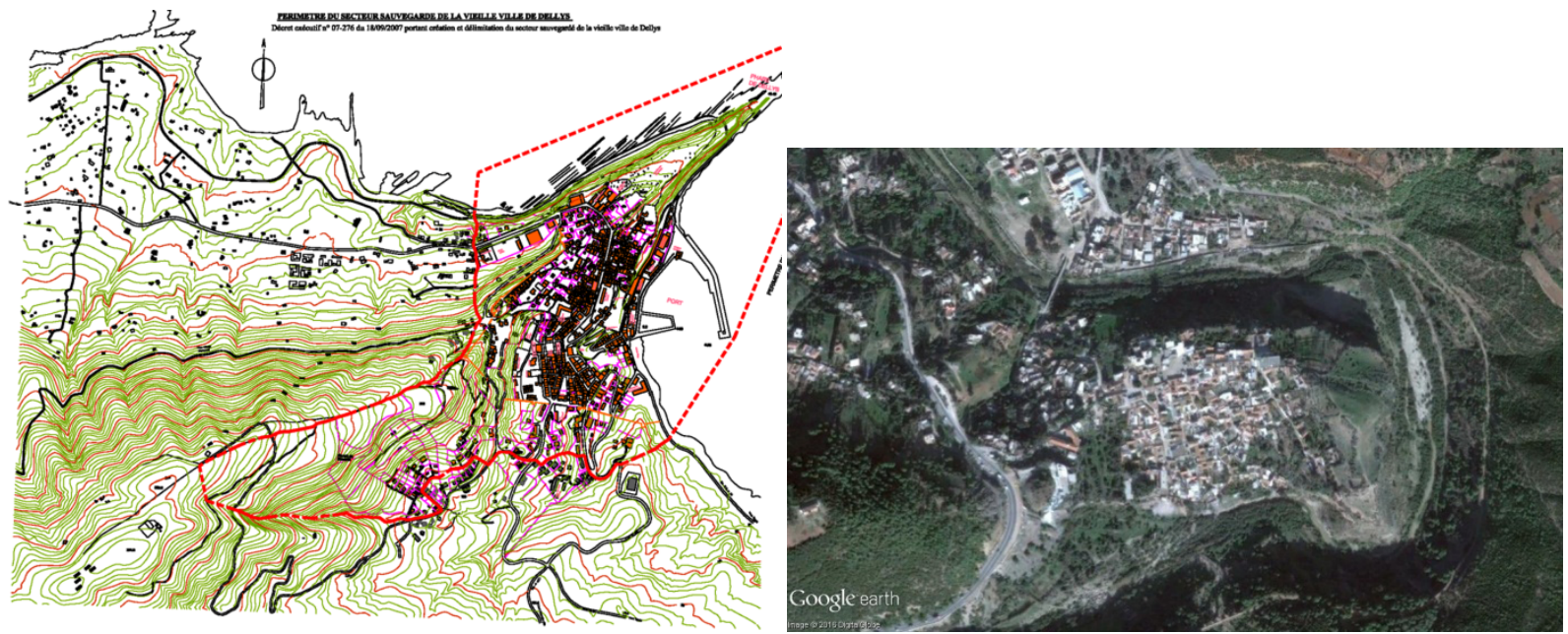

Fig. 2 Images from left to right: the saved sectors of Dellys and Ténès.

in protected sectors in $2007 .^{3}$ They are all the time subjected to seismic risk. The two conservation areas are covered by PPSMVSS (Fig. 2).

The protected area of the old town of Dellys is submitted for likely publication in the Official Journal. The protected area of the old town of Ténès is in the

\footnotetext{
${ }^{3}$ Executive decree no.07-276 on September 18, 2007 about creation of saved sector of the old town Dellys. Executive decree no.07-277 on September 18, 2007 about creation of
} saved sector of the old town Ténès. final editing phase. Both PPSMVSS were established in three phases.

Phase One of the project is diagnosis and emergency measures. Diagnosis is made in situ, and it highlights the frame of the conservation status of the various networks and determines the pathologies. In purpose of this phase, a project of emergency measures was proposed.

Phase Two is historical and typological analysis and 
first draft project PPSMVSS parallel to the diagnostic and emergency measures. The fixed permanent safeguarded plan a number of land use rules, constraints to respect and special protection measures. It also determines the conditions under which architectural conservation is assured the built environment of the entire protected area.

The fabric typo morphologic analysis is particularly well suited for this type of study. It is based on a thorough reading of the conservation area fabrics referred in its historical, typological, architectural and constructive components.

In addition to the historical and typo morphologic studies of the conservation area, the various aspects of the area are developed as follows:

- physical and geotechnical study;

- demographic and socio-economic study;

- environmental study;

- study of the various networks.

A summary of these analytical studies enables the identification of existing interactions. After which, regulations and the guidelines for development are taken, aiming an integrated conservation and coherent development for this sector.

On referring to the Art. 18 of Executive Decree No. 05-318 of September 10, 2005, laying down the procedures for the preparation and approval of the land use plan, a map of the areas and land exposed to natural hazards and/or technological, classified according to their degree of vulnerability, must be established [10].

Phase Three is final editing of PPSMVSS. Once the second phase is approved, following a consultation with the different actors involved in the management of this plan, the final draft of the safeguard plan and permanent saved sector and enhancement is developed in accordance with the content of Executive Decree No. 03-324 of October 5, 2003 laying down rules for the establishment of the PPSMVSS $[11,12]$.

We found that the cards: geotechnical, easements and built environment of the conservation status are the only superficial address for the easement of natural and technological hazards. The identification and classification map of seismic zones according to the degree of vulnerability of the two conservation areas is not established. ${ }^{4}$

\section{Conclusions}

After a decade of the earthquake that whipped Algeria in 2003, the safeguard sectors of the old towns are still fragile due to this seismic hazard.

In this situation, guidelines are proposed to complement the content of the safeguard permanent plan and enhancement (PPSMVSS) to prevent the seismic risk:

- the identification and classification of seismic areas of these safeguarded sectors according to their degree of vulnerability;

- establishment of vulnerability maps of the safeguarded sectors and seismic micro zoning;

- establishment of a general prevention plan.

Today, managers must take action of preventing anticipation, forecasting and natural risk management by integrating them into the different policies they put and implement in the time and the space.

\section{References}

[1] SGG. 1998. Law No.98-04 on June 15, 1998 Relative to the Protection of the Cultural Heritage.

[2] SGG. 2004. Law No. 05-04 on August 18, 2004 Relative to Land Use Planning and Development.

[3] SGG. 2004. Law No. 04-20 on December 25, 2004 Relative to the Prevention of Major Hazards and Disaster Management within the Framework of Sustainable Development.

[4] Ferrigni, F., and Helly, B. 1990. Protection of the Built Heritage in Seismic Areas: Analyzes and Interventions. Strasbourg: PACT.

[5] Feilden, B. M. 1987. Between Two Earthquakes : Cultural Property in Seismic Zones. Los Angeles-Rome: Getty Conservation Institute-ICCROM.

[6] UNESCO. 2010. Managing Disaster Risks for World Heritage, Reference Manual. UNESCO.

${ }^{4}$ Card enacted by Article No. 18 of the Executive Decree No. 05-318 on September 10, 2005, amending and supplementing the Executive Decree No. 91-178 on May 28, 1991, laying down the procedures for the preparation and approval of the land use plan. 
[7] UNISDR. n.d. "Terminology for Disaster Risk Reduction." UNISDR. Accessed May 23, 2013. http://www.unisdr.org/eng/library/lib-terminology-eng\%2 Ohome.htm.

[8] Directorate of Culture Wilaya of Boumerdes. 2014. The Permanent Plan for the Safeguarding and Development of the Old Town of Dellys. Directorate of Culture Wilaya of Boumerdes.

[9] Directorate of Culture Wilaya of Chlef. 2014. The Permanent Plan for the Safeguarding and Development of the Old Town of Ténès. Directorate of Culture Wilaya of Chlef.
[10] SGG. 2005. The Executive Decree No. 05-317 on September 10, 2005, Laying down the Procedures for the Preparation and Approval of the Master Plan for Management and Urban Planning.

[11] SGG. 2005. The Executive Decree No. 05-318 on September 10, 2005, Laying Down the Procedures for the Preparation and Approval of the Land Use Plan as Well as the Content of Documents Relating Thereto.

[12] SGG. 2003. The Executive Decree No. 03-324 on October 5, 2003 Laying down Detailed Rules for the Establishment of the Permanent Plan for the Safeguarding and Development of the Saved Sectors (PPSMVSS). 